\title{
The Importance of Iconic Buildings for City Image: Konya Science Center Example
}

\section{Abstract}

Science centers are experimental and applied places that are designed to pave the way for people from all age and with different knowledge to learn the information from the source and to trigger their interest towards science. Science centers convert science into an education in an entertaining manner. Moreover, science centers can be defined as places that exhibit history and culture of the geography that are present in addition to their contribution to science, while being places where science and art are merged to each other in harmony. In recent period, scientific events may create attraction for cities in addition to cultural events, Science centers, where education is found together with entertainment, are now becoming more and more popular in the world and they can sometimes serve as an important focal point of the city by attracting more visitors from certain museums. It is seen in recent period that science centers are being designed as iconic buildings with the purpose of creating attention with their different architecture. Science centers, which are designed as iconic buildings with their interest and curious architectural designs, create a new attraction point by drawing tourists to the city along with the educational activities.

The aim of this study is to reveal the opinions of the architect in the design of Konya Science Center, to analyze the relationship established by the
Keywords: Science centers, icon building, iconic science center, identity of center

*Dr. Emine Ylldız Kuyrukçu, Faculty of Architecture \& Design, Department of Architecture, Konya Technical University, Konya, Turkey. E-mail: mimar-emine@hotmail.com Orcid ID: http://orcid.org/0000-00025794-3507 
building with the city, its scale with surrounding texture and human, the access to building, its form, material, technology and its spatial presentation to determine whether it is an iconic building or not. For this purpose, science centers' design purpose and their importance for the city are explained firstly, then examples across the world are given. Observations and interviews are made, photographs of the building are taken and any kind of written and drawn resources are utilized in order to determine whether the selected building is in accordance with the definition "iconic building".

As a result, it is determined with this study that Konya Science Center is "an icon building" for the city in parallel with the developing trends in design and construction technology fields in general terms after its analysis in architectural terms. It is hope that Konya Science Center that is featuring icon building will be attention center for Konya city after Mevlana Museum because of owing to its different form, material selection, building and Leeds certified sustainable building.

\section{INTRODUCTION}

Science centers, which were established in order to make science more popular among wide masses and where education and entertainment were found together, started to give service in 1960 's. Science centers are places where entertainment and education stand together and allow visitors to make examinations just like a real scientist (Weitze, 2003). Science centers, which try to introduce science to non-specialized people in order to make it more popular Persson (2000a), are places where ideas in the world are discovered, researched and tested. It addresses to people from all age groups, culture and educational levels, it satisfies their curiosity, gives response to their questions, ensures their active participation to experiments and allows them to explain the things they learn to other people. Visitors repeat experiments in an interactive environment at science centers and understand thinking like a scientist (Weitze, 2003). With these exhibitions, which transfer information not with classical methods, but with visual, audial, interactive mechanisms that address to emotions, visitors experience scientific facts in an interactive way with computer programs, mechanical and electronic mechanisms, even with simple wooden toys sometimes. It is seen that science centers have unique features of the region they are present within their building, therefore it becomes easier for local visitors to identify science by themselves, while chances are offered for foreign visitors for getting idea about the identity of the city.

In competition conditions that increase depending on the global developments, cities try to differ themselves from other similar cities and be more preferable by this way. In order to develop their images, cities are pushed towards warning city development, 
while having pressure towards producing creative solutions to attract more investors and visitors (Richards and Wilson, 2004). One of these solutions is "iconic building" design in the city. Iconic buildings can be defined as symbol buildings, icon buildings, city icons as well. The common quality of iconic buildings is the condition that they become icon of the city, region or country, where they are present. They are the buildings that make people refer to the space they are present with the name of the iconic building (Avcl, 2015; Ateşoğlu, 2008). These buildings draw attention with their designs, concepts or technologies that are used. By attracting the attention of many individuals, buildings draw more visitors to the place. In terms of Iconic buildings, we see their examples in many cities, they provide many contributions to the city they are present in socio-cultural and economic terms.

In addition to cultural events, scientific events also create attraction for cities as well and science centers can be designed as iconic buildings. Science centers, which offer the possibility to visitors of experiencing science as "iconic building" by having values like visibility, transparency together with different dimension, architectural buildings, material selections with many different examples in the world, that are becoming more and more popular in the world and may become an important focal point of the city.

Scientific and Technologic Research Council of Turkey (TÜBİTAK) made the first official project call in 2008 in order to support science center studies in our country. Konya Science Center, which is a project of Konya Metropolitan Municipality, is the first project of this call. Within the scope of this study, Konya Science Center is selected as the example field and it is analyzed in architectural terms whether it carries the quality of "iconic building".

\section{DEFINITION OF SCIENCE CENTER}

According to ASTC, science centers can be defined as a place where visitors are connected with science, given curiosity, wonder, encouragement, and first-hand experience, and provided lifelong learning. Emphasizing the social aspect of science centers, Rennie and McClafferty (1995) proposed their definition as a social event having strong affection on behavior and learning. Another important characteristic of science centers is that they are informal learning environments, where learning and entertainment mix together (Weitze, 2003), by allowing visitors to touch, play, and experiment with the exhibits (Quin, 1990). Science centers; 
- give a chance to everyone to try experiments (Persson, 2000b; Falk \& Dierking, 1992).

- provide people to participate in experiments actively, and use all their senses (Weitze, 2003).

- make people notice effectiveness of science for a society; and improve public awareness of science (Rix and McSorley, 1999).

- provide "exploration of scientific and technological phenomena" (Quin, 1990).

- provide students an entertaining environment less formal than a classroom (Lucas, 1983; Ramey-Gassert L., 1996).

- "can provide hands-on, exploratory science learning in a non-evaluative, relaxed context by offering science through real-world objects and natural phenomena" (Ramey-Gassert L., 1997).

- provide social interaction that was essential source of satisfaction in science center visits and peer-teaching for students (Carlisle, 1995 as cited in Rennie \& McClafferty, 1996).

- provide teachers to discover the interactive presentation techniques presented in science centers (Lucas, 1983).

- promote interest and curiosity, and make people notice how the world works (Russell, 1990).

- make a great deal of contributions to the affective domain of the students which includes generating wonder, enthusiasm, excitement, motivation, interest, awareness, and attitudes that affect their learning (Gammon, 2008; Rennie \& McClafferty, 1995; Wellington, 1990).

\section{DEVELOPMENT PROCESS OF SCIENCE CENTERS IN THE WORLD}

The developments of science museums in the last two centuries can be summarized as follows (Hannu, 1993);

\section{Science Centers in 19th Century}

The oldest science center was the center that was formed by Francis Bacon (1561-1626) with empirical scientific method. This classification created the main ideology of science centers and Ashmolean Museum, which was established inside Oxford University in 1683, is considered as the first science museum. The history of the nature is being exhibited at this museum. The first large-scale science and technology museum is Musee National des Techniques museum that was opened in Paris in 1799. The museum aimed to explain science and technology to teachers, students and public. In addition, various scientific tools and devices, along with their theories and working principles are 
shown systematically at London Science Museum, which was established in 1857. In those years, Franklin Institute in Philadelphia and Smithsonian Institution in Washington were established in the U.S.A. with great efforts.

\section{Science Centers in 20th Century}

Deutsches Museum, which was founded with the efforts of Oscar Von Müller in 1903, formed a modern example of science centers. At this museum, interactive exhibitions that can be touched and experienced by visitors were placed emphasis. Moreover, Planetarium that was opened at the museum in 1925 was the first example of its kind. Museum of Science and Industry in Chicago is the first science museum established in the U.S.A. with the quality of a German Museum. The first full-scale Science and Technology Museum in the U.S.A. was The Henry Ford Museum that was founded in 1929. Following this museum, New York Museum of Science was established in 1935. The Palace of Discovery that was founded in Paris in 1937 was a building with the first modern science center identity. Different than the exhibitions at Deutsches Museum and Museum of Science and Industry in Chicago, modern science and technology was explained at the main level at this center along with efforts to provide contribution to education with various interactive exhibitions.

In 1950's, fast technical developments in industrial society had great impact on developments at interactive science museums and this change at science museums gained pace in 1960's. Exploratorium that was opened in San Francisco in 1969 and Ontario Science Center that was opened in Toronto the same year were new corporations where learn by experience approach was fully applied on exhibitions.

In today's world, there are more than 3.000 science centers. The annual visitor number of these centers exceeds 200 million. One out of every three people in the USA goes to science center at least once a year. Almost all of the science centers become dense in developed countries like America, Japan and Europe. There are scarcely any in developing countries. India is an exception and today there are close to fifty science centers in India.

\section{THE IMPORTANCE OF ICONIC BUILDING FOR CITY IMAGE}

The image of a city is usually very important in attracting visitors. One of the most efficient factors in the establishment of city icons throughout the history are the buildings the iconize that city. Architectural icons create the image of the city and cities differ from each other and remembered with these icon buildings. Icon buildings are the most dominant elements of city icons and they 
act as an indispensable part of cities. Over the last few decades the term "iconic" has entered common usage for those in and around architecture with a considerable overlap into the mass media. What does it mean to say that a building or a space or an architect is 'iconic'?

Icon is an image, figure, or representation; a portrait; an illustration in a book; image in the solid; a statue. Iconic buildings are mostly considered as symbols that represent the city or country they are built in. But they are not to be confused with monuments; which are buildings that have a historic value or a connection to the history or culture of place or person. Iconic buildings in general, are noticeably different, in terms of design, size, visual appeal, urban fabric, building style etc. they have an impact on people and the place in which they are built. Their lasting impression is what makes them iconic. Iconic architecture is so unique it is associated with and becomes one of the symbols of a place.

Iconic buildings are the ones that have their place in social memory and acted as centers of attentions throughout the history. They carried importance with their qualities like being religious, functional, etc. they had in their time, then they became icons through time (Lökçe 2003). Architectural icons like Eiffel Tower, Taj Mahal, Pisa Tower recall the cities they are found, while being defined on our minds as city icons. (Maralcan, 2006).

Figure 1. Eiffel Tower-Paris/France and Taj Mahal-Agra/India (URL-1; $U R L-2)$.
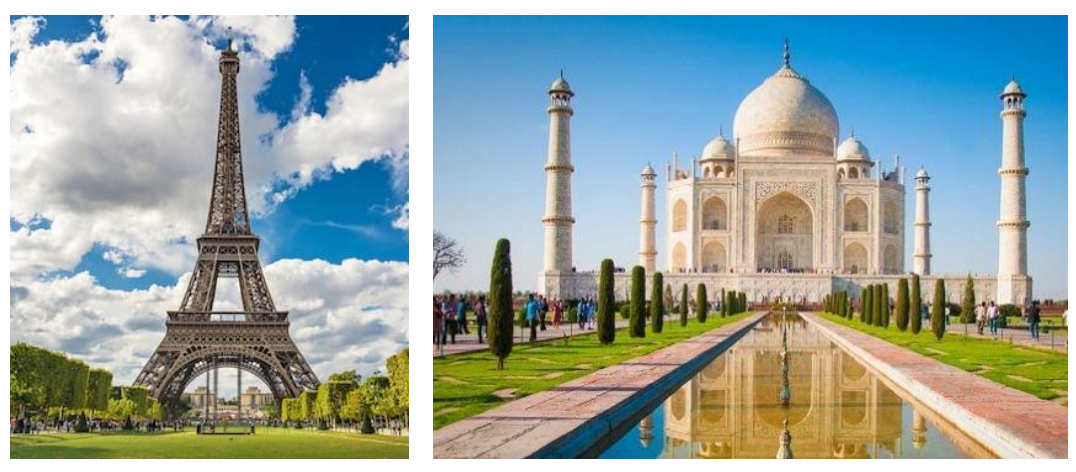

These buildings, which are powerful icons that are created on social memory, have been center of attention for humanity from past to today's world. (Ekenyazıcl, 2005; Engez, 2007). In fact, these buildings became more popular than the cities they are present. One of them is Sydney Opera House in Australia. Sydney's most famous icon, acclaimed as one of the most outstanding buildings of the 20th Century. Designed by Danish architect Joern Utzon, and taking 14 years to complete, he resigned mid-way through construction due to political interference, never to return. The Opera house building is seen as icon of Australia by its formal design. The unique style of the building comes from pure curving 
shapes that across the harbor in great heroic harmony that represents a masterpiece of modern architectural design, engineering and construction technology in Australia and also Since opening its door in 1973, the Opera House has become a symbol of modern Australia and one of the country's major tourist destinations (Figure 2).

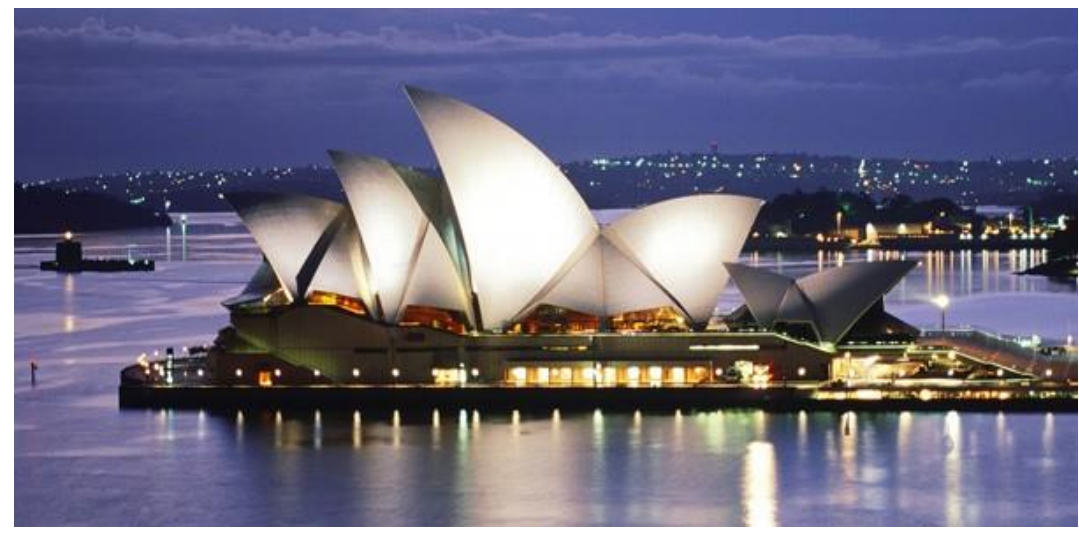

Cities need to find new ways because of distinguishing themselves from their competitors. As Paddison (1993) points out, city marketing is often directed at the levering of private capital to support infrastructural developments. For example, icon buildings frequently feature in urban strategies to develop an image or 'brand' and create competitive advantage, often at great financial cost. Recent examples include the Bilbao Guggenheim museum, Australia the Tate Modern gallery in London and the Baltic Flour Mills in Gateshead.

After the Guggenheim Museum opened museum makes a significant economic contribution to the city's economy and this called in literature the "Bilbao Effect". The Guggenheim museum Bilbao which is a museum of modern contemporary art, designed by Canadian architect Frank Gehry, built by Ferrovial, is located in Bilbao Basque Spain. The museum is designed and covered with glass, titanium and limestone. When we consider material usage of the building it indicates the technology usage. The curves on the exterior of the building were intended to appear random; "the architect said that the randomness of the curves is designed to the catch the light." The museum building is an icon of the city Bilbao Every year millions of tourists are coming to see Bilbao (Figure 3).
Figure 2. Sydney Opera House, Sydney/Australia, Joern Utzon, 1973 (URL-3). 
Figure 3. Guggenheim Museum, Bilbao/Spain, Frank Gehry, 1997 (URL-4).

Figure 4. 30 St Mary Axe, London/England, Norman Foster, 2003 and Burj Khalifa, Dubai/ UAE, Adrian Smith, 2010 (URL-5; URL-6).

Figure 5. Heydar Aliyev Center, Baku/Azerbaijan, Zaha Hadid, 2012 and CCTV Headquarters, Beijing/ China, OMA, 2012 (URL-7; URL-8).



The iconic buildings are seen as a symbol of cities that are racing on the global platform and are perceived as enhancing the attractiveness of the cities. Iconic buildings where contemporary architectural practices are applied are shaped by different design approaches such as based on urban context, program proposal, innovative design, tabula rasa concept design or approaches that are re-evaluated city's historical or cultural heritage. In the process of urban image design, the iconic buildings that are focused on demonstration added to the city are increasing day by day (Figure 4-6).
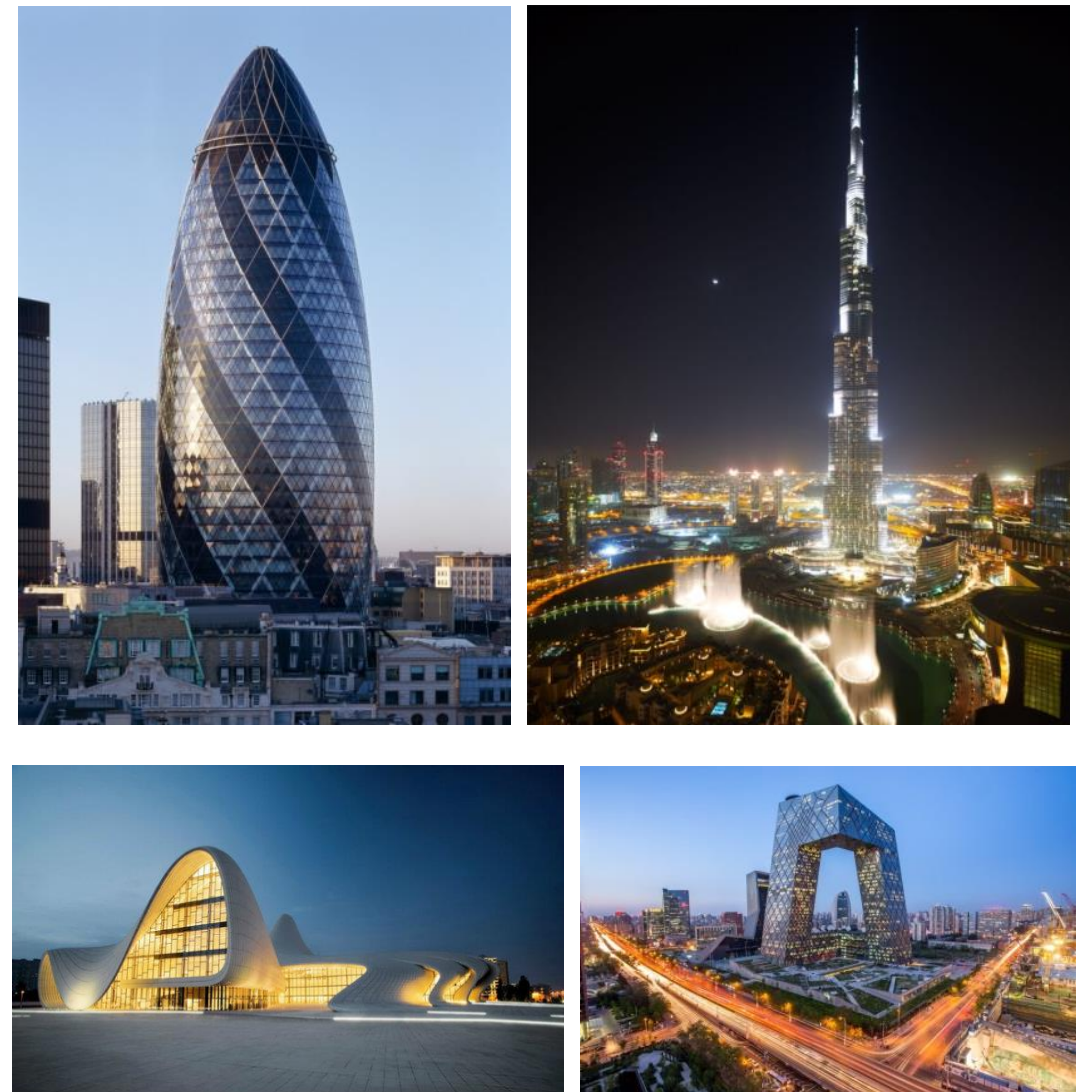
The Importance of Iconic Buildings for City Image: Konya Science Center Example
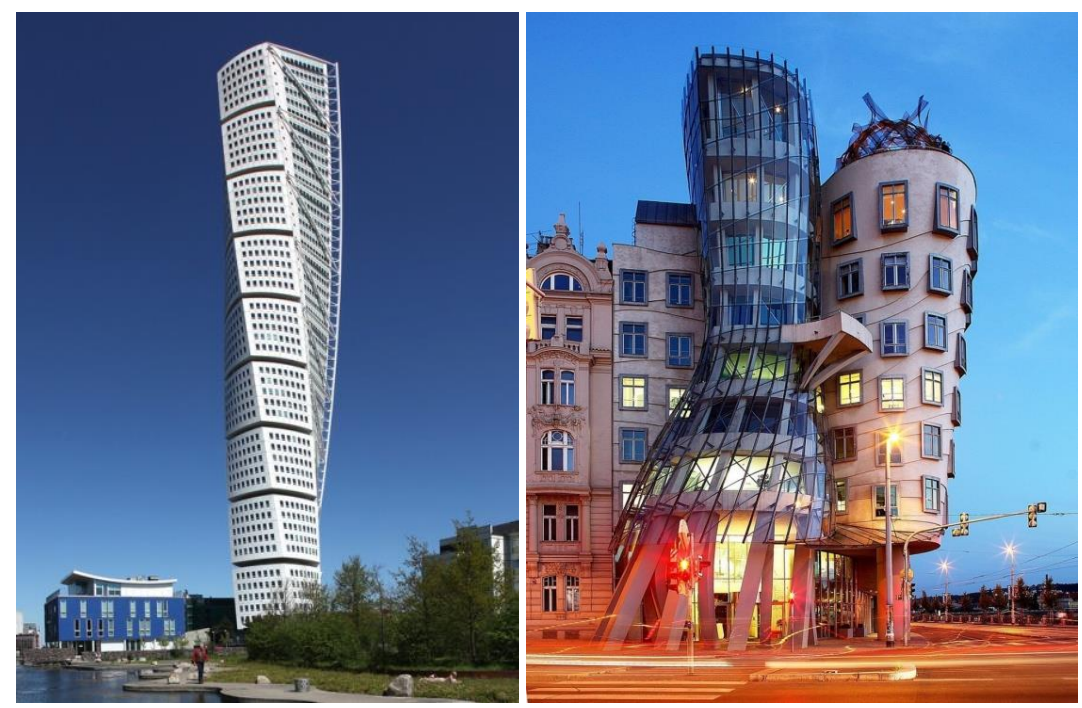

Modern architecture icons respond to icon pursuit of countries, while acting as powerful symbols as the representative of city icons. We look through architectural view, for a building to be iconic, it must consist or have variety of integrated features such as;

1. Unique design (different and original)

2. Large scale

3. High level (new construction technologies and materials)

4. Spectacular representation (landmark)

5. Specific message signification by the building (metaphoric forms).

With the developing technology digital techniques have provided great advantages in the design process and caused to be radical changes in the architectural formation with their rapidly increasing number, popularity and interesting forms, iconic buildings turned to be the mostly applied architectural structure on city actors' identity search for globalized city.

\section{THE EXAMPLES OF ICONIC SCIENCE CENTERS FROM THE WORLD}

Science centers contribute to personal and social development of individuals while providing economic contribution to the city where they are present. Each year more than 200 million people visit science centers or at attend a science center event once a year. Science centers create brand effect in the city and attract many visitors and provide economic contribution as well. There are many science centers in the world that draw the attention of visitors with their different architectural designs to be icon building and attract more visitors. Below, we see science centers that became icon building of the city their different architectural designs (Figure 7-15).
Figure 6. Turning Turso, Malmö/Sweden, Santiago Calatrava, 2005 and Dancing House, Prague/Czech Republic, Frank Gehry, 1992 (URL-9; URL-10). 
Figure 7. Museu de les Ciències, Valencia/Spain, Santiago Calatrava, (URL-11).

Figure 8. Shanghai Science and Technology Museum, Shanghai/ China (URL-12).

Figure 9. Scientific Center of Kuwait, Salmiya/Kuwait (URL-13).

Figure 10. Phaneo Science Center, Wolfsburg/Germany (URL-14).
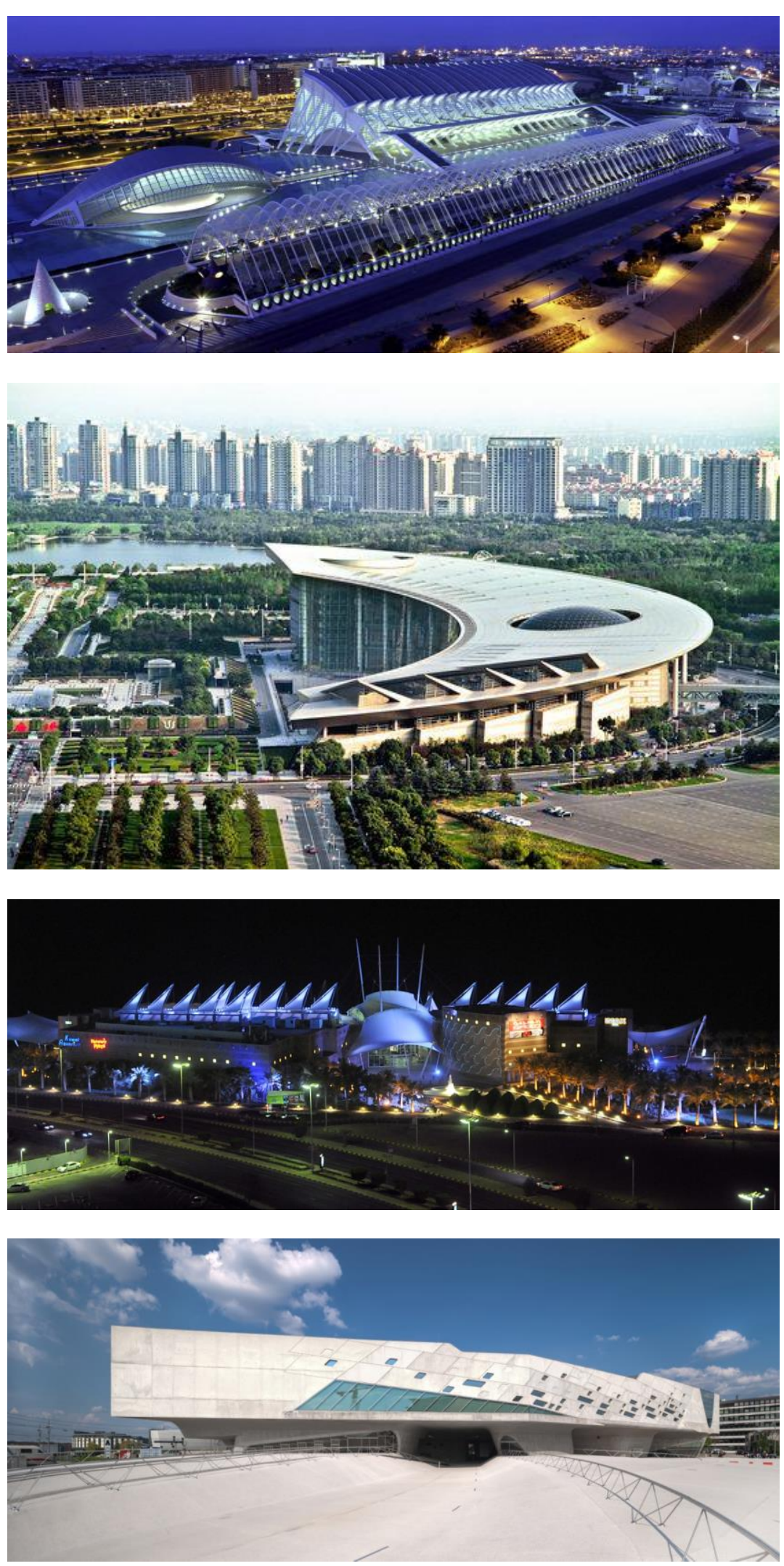
The Importance of Iconic Buildings for City Image: Konya Science Center Example
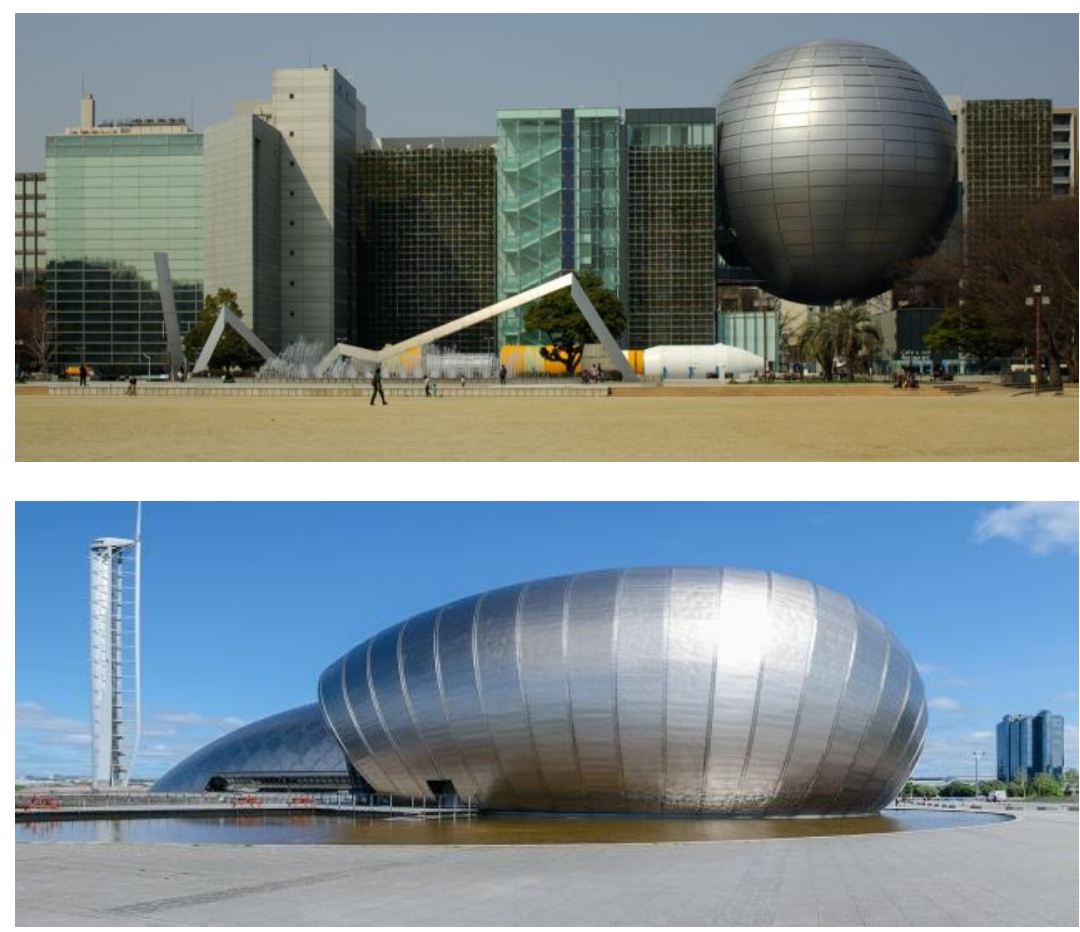

471
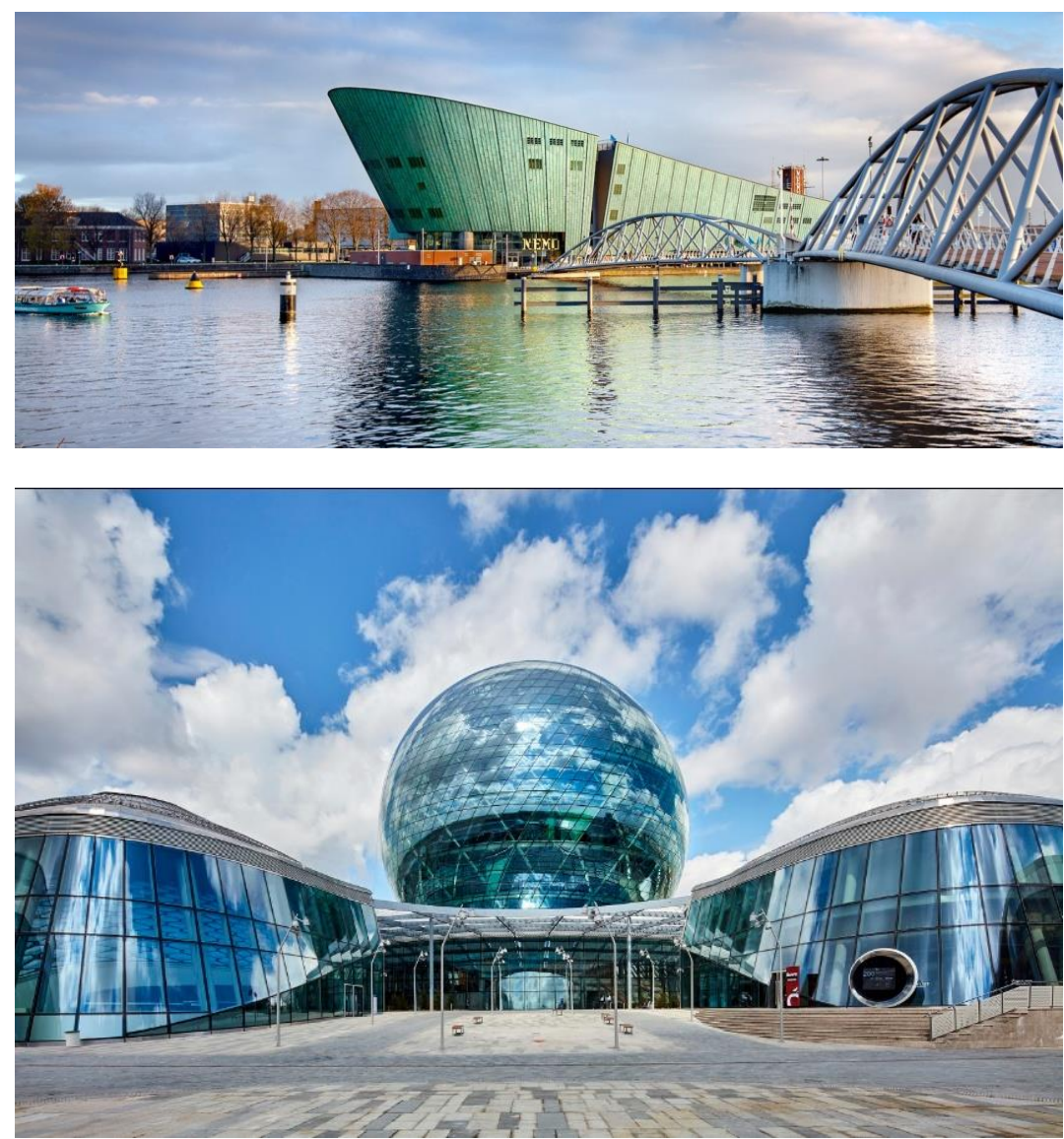

Figure 11. Nagoya City Science Museum, Nagoya/Japan (URL-15).

Figure 12. Glasgow Science Centre, Glasgow/Scotland (URL-16).

Figure 13. NEMO (National Center for Science and Technology), Amsterdam/Netherlands (URL-17).

Figure 14. Kazakhistan Pavilion and Science Museum, Astana/ Kazakhistan $(U R L-18)$. 
Figure 15. Artscience Museum, Singapore (URL-19).

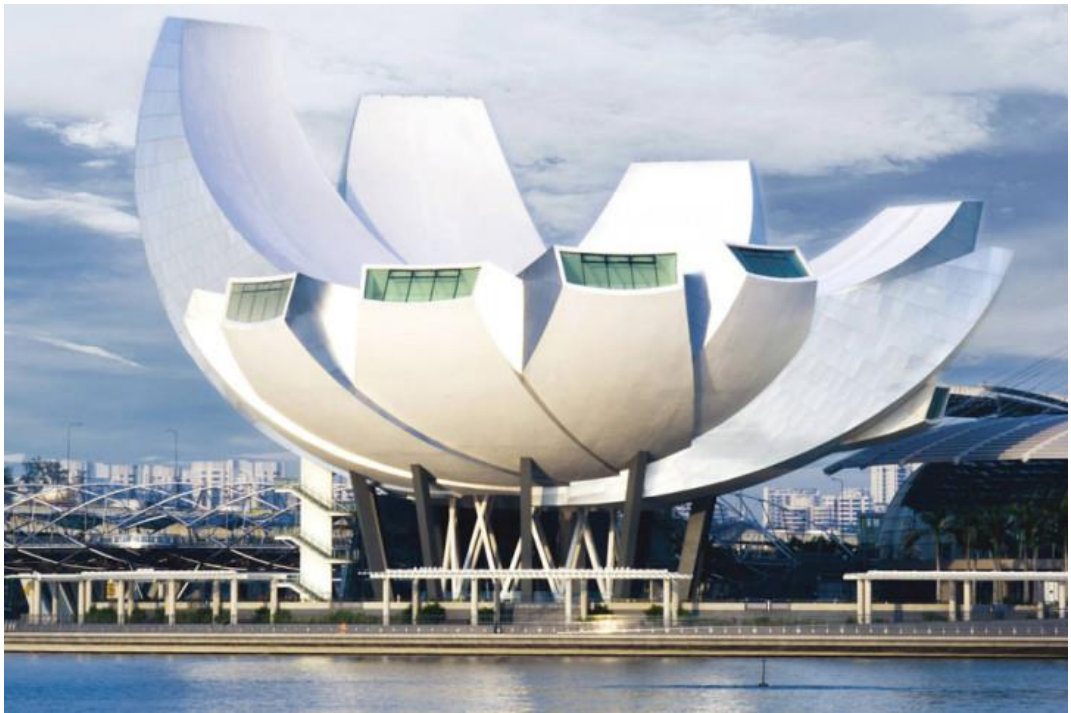

These buildings draw attention with their designs, technologies that are used or with their concepts. These "iconic buildings" that are designed by hit architects as a result of contest projects affect the city they are present along with its physical environment. After a while, the city, where these buildings are present, is referred with them and it increases the popularity of the city. The number of visitors who visit these science centers and the expenses they make create an important source of income for the city and creates an employment effect.

\section{MATERIAL AND METHOD}

The number of iconic science centers continuously increases in the world and they have great impacts on the city image. It is seen that the last period science centers are designed iconic with different architectural forms and they are the focal point for the city. From this point of view, within the scope of this study, Konya Science Center is selected as the example field and it is analyzed in architectural terms whether it carries the quality of "icon building".

In this study, firstly concepts related, science center, icon, iconic building, iconic science center are defined. Secondly, iconic buildings' impacts on city image and city identity are investigated by the help of selected reference building and icon science center examples are given. Finally, contribution of iconic science centers to the formation of global city and identity as an architectural formation are emphasized. The aim of this research is to determine the general characteristics of the icon structures and to question the Konya Science Center through these features. For this purpose, observations and interviews are made, photographs of the building are taken and any kind of written and drawn 
The Importance of Iconic Buildings for City Image: Konya Science Center Example

resources are utilized in order to determine whether the selected building is in accordance with the definition "icon building".

\section{IS THE KONYA SCIENCE CENTER ICONIC BUILDING FOR KONYA CITY?}

General Information about The Konya Science Center Project Scientific and Technologic Research Council of Turkey (TÜBİTAK) published "the Call to Establish Science Centers" on March 27, 2008 in order for people to comprehend the importance of science centers in increasing attention towards science in Turkey and make them widespread around the country. Within the scope of the call, the plan was to give support to the project of establishing a Science Center in one of our cities with metropolis status. Governors, mayors of 16 cities with metropolis status along with the chairmen of the chambers of industry and commerce have attended this call. Project recommendations were prepared by metropolitan municipalities of 6 cities and then one metropolitan municipality left the process with their own will. As a result of the field examination; Konya Metropolitan Municipality gained the right to host the first Science Center that is planned to be established in many cities of Turkey with the support provided by TÜBİTAK (Aydın, 2010).

Konya Science Center, which is the first science center that is supported by TÜBİTAK, is constructed on a 99.347 square meters field in Organized Industry Region on Ankara - Konya highway in Büyük Kayacık Neighborhood, Ankara Boulevard, Selçuklu District of Konya. It is positioned on $25 \mathrm{~km}$ distance to city center. Konya Airport is situated ahead of the project in organized industry region (Figure 16). 
Figure 16. The Location of Konya Science Center (URL-20).

Figure 17. General View of Konya Science Center (URL-21).

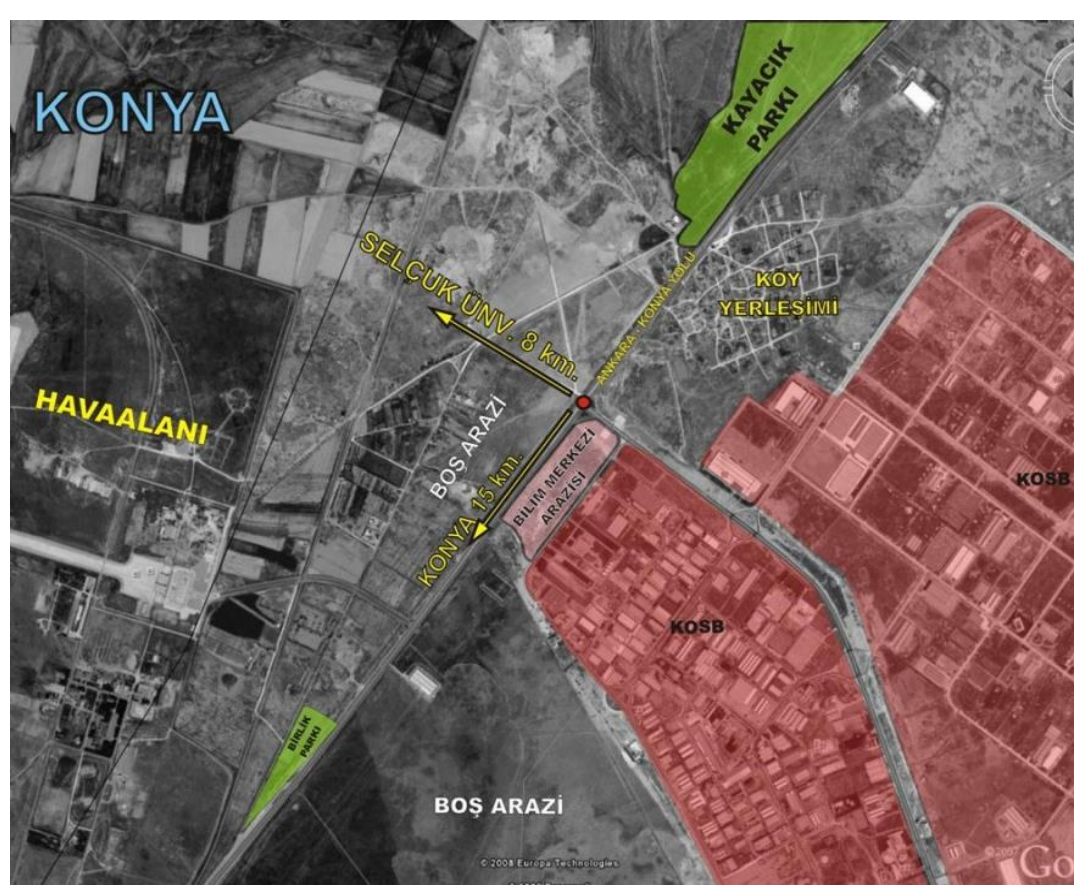

Konya Science Center is the first international scale science center of Turkey with 26.248 square meters indoor space and 14.000 square meters of outdoor car parking space along with vehicle roads, 11.000 square meters of walking roads and 47.000 square meters of green fields with thematic exhibitions, outdoor exhibitions, observation and scenic tower, Planetarium, conference halls, laboratories and libraries. With its extraordinary architecture, Konya Science Center is designed by Architect Selim SOMONCU - A Proje setting off from the idea that it shall provide important contributions to the establishment of scientific mentality in our country (Figure 17).

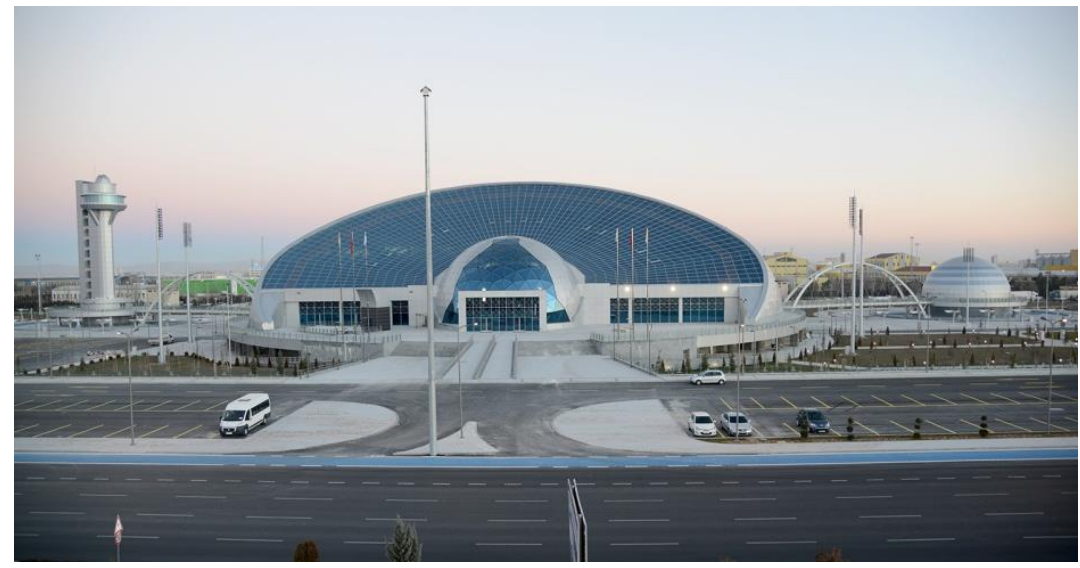

The Analysis of Konya Science Center in terms of Architectural

Konya Science Center consists of 3 buildings that are connected to each other with bridges; main building, planetarium, observation and scenic tower. Science center's main building, which consists of basement, ground floor, 2 normal stories and a garret, is $110 \mathrm{~m}$ 
The Importance of Iconic Buildings for City Image: Konya Science Center Example

wide and $30 \mathrm{~m}$ high in a geodesic form. It is the biggest project in Turkey that is made with this system. In 134 square meters space of glass front cutting of Konya Science Center, photovoltaic batteries are used to get electricity from solar energy (Figure 1819).
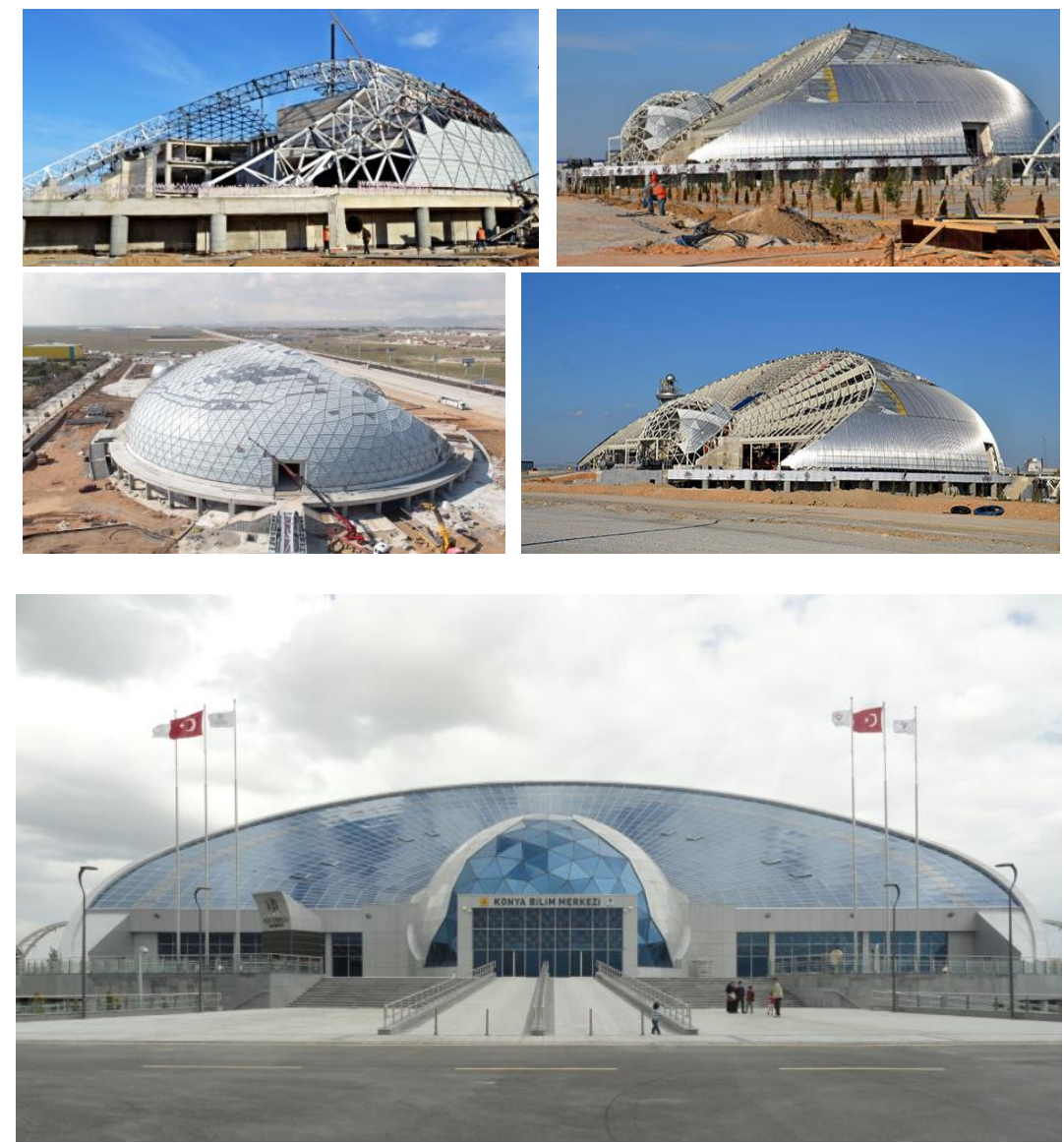

The main building is raised by 2 meters above the level of the road by benefiting from the inclined structure of the land, thus the below ground level of the building is taken to garden level. The siding of the main building is designed as Seljuk ornament sanding pattern study on tempered glass (Figure 20).

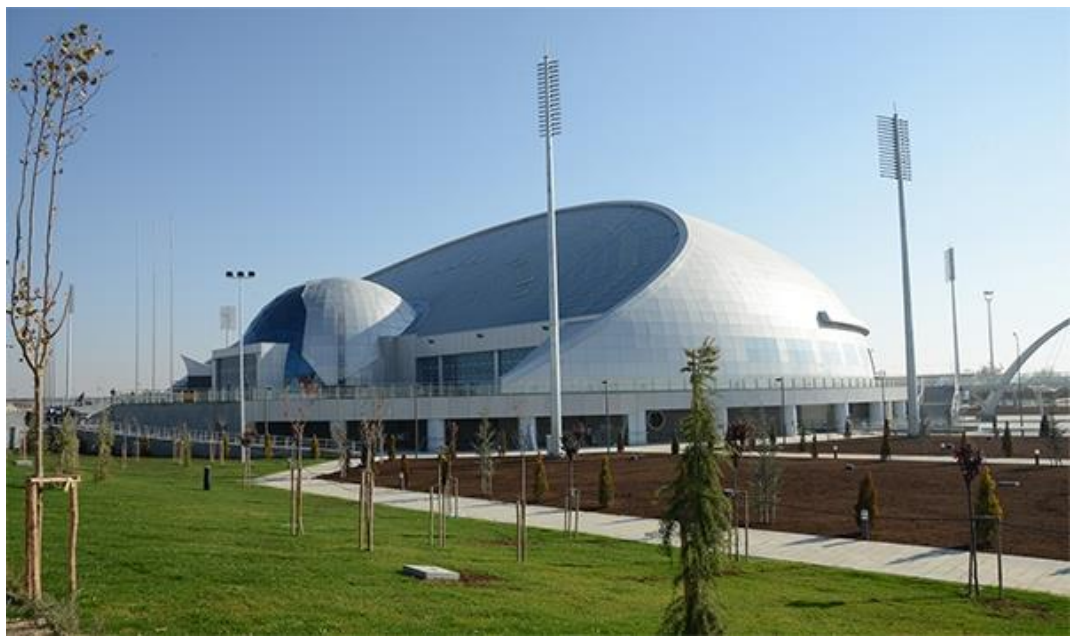

Figure 18. Konya Science Center Main Building Steel Netting Shell System Construction Stages (URL22; URL-23; URL-24; URL-25)

Figure 19. Konya Science Center Main Building Entrance Side Latest Condition (Photo: Emine YILDIZ KUYRUKÇU)

Figure 20. The siding of main building (URL-26) 
1.300 square meters wide and magnificent foyer area welcomes visitors coming to Science Center building. From this area, access is provided to book sales unit, education units, exhibition halls and planetarium and observation house via bridges (Figure 21).

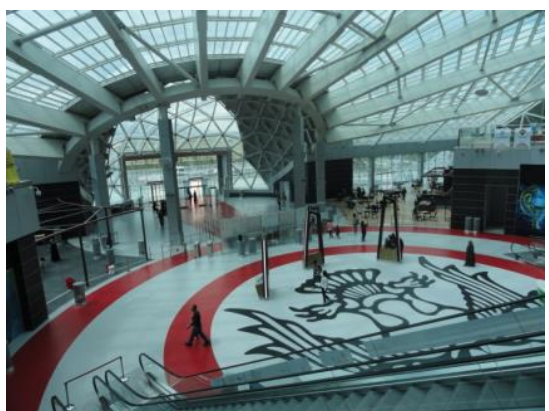

Entrance



Exhibition halls

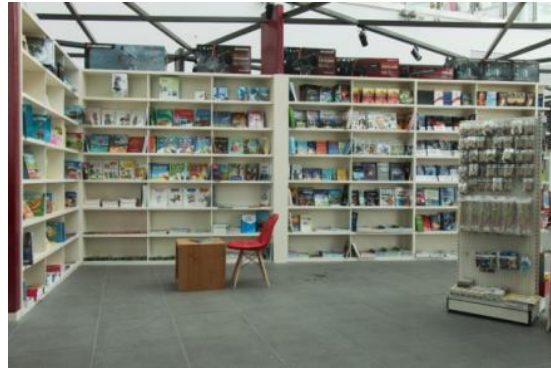

Book sales unit

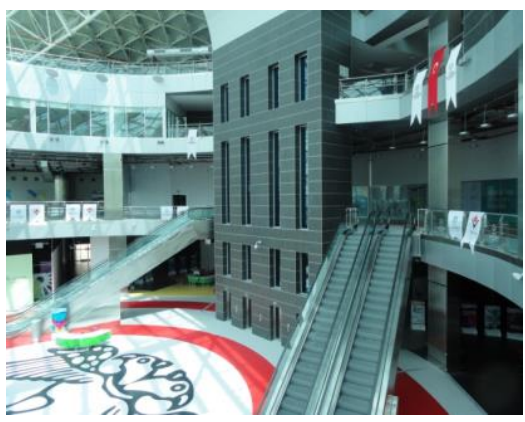

Foyer area

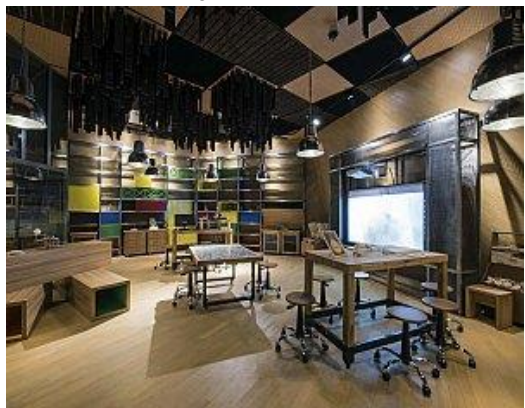

Education units

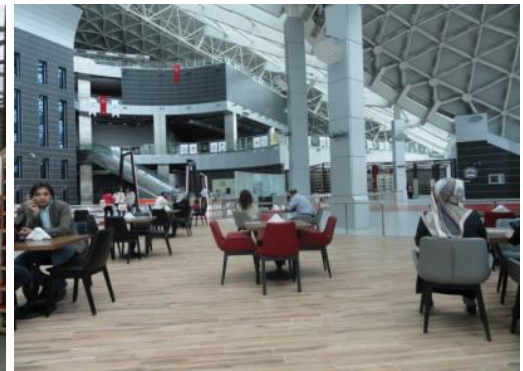

Cafe YILDIZ KUYRUKÇU)

Planetarium, which can be accessed via main building by visitors, is 24 meters wide and 12 meters high while having a geodesic form. Planetarium, which is also known as 'planet house' in Turkish language, has a dome shape and images are reflected on each side of the dome. Therefore, viewers may watch shows with 360-degree angle and with 3-dimention method (Figure 22). There are indoor and outdoor spaces in these places, where celestial bodies and events can be watched. The solutions of Konya Science Center project are realized by Icosa Systems Company. The company was given "Awards of Merit" award at The International Federation of Consulting Engineers (FIDIC) 2014 held in Rio De Janeiro with this project. 
The Importance of Iconic Buildings for City Image: Konya Science Center Example

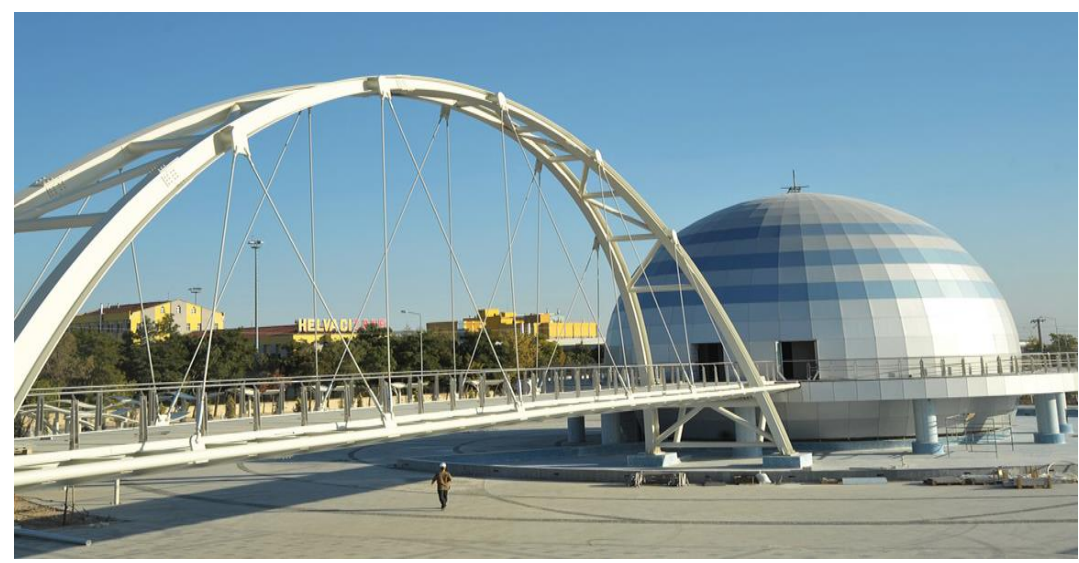

Observatory with 42 meters height and 150 square meters floor space is present as the $3^{\text {rd }}$ building. Composite panel siding is applied to exterior side of the building. Scenic and Observation Floor are present in this building, where celestial bodies and events may be watched (Figure 23).

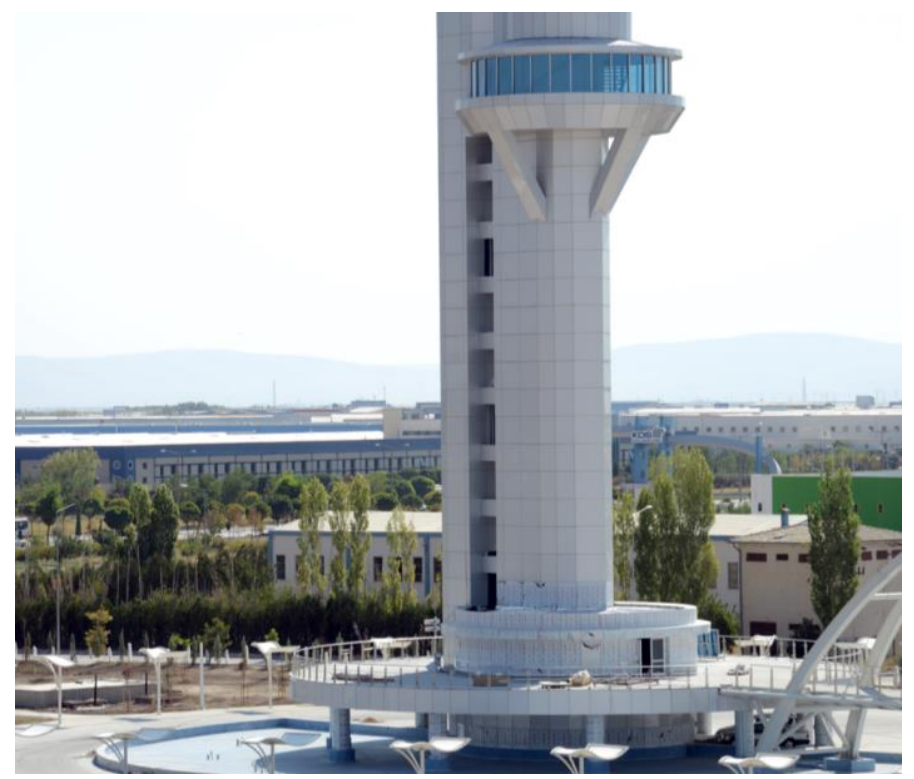

Two units of 600 square meters luxury water tanks are constructed in order to benefit from rain water in garden watering system. Special tunnel type holed drainage pipes are used for the infrastructure of landscape areas found around the project. Electricity with windmill system is positioned in the garden of Science Center.

It is seen that the first science center of Turkey that is supported by TÜBİTAK, there are planetarium, observatory, exhibition halls, laboratories, places where scientific developments can be transmitted are present. As a result of the analyses made on the subject It is determined that Konya Science Center is an icon building for Konya because it has iconic building features such as unique design (different form), large scale, new construction
Figure 22. Planetarium of Konya Science Center (URL-27)

Figure 23. Observatory of Konya Science Center (URL-28) 
technologies and material selection, landmark, carried specific message signify by the building. As a result of the observations and interviews related with the structure and, it is seen that an important attraction point for visitors coming to the city and it provides important contributions in terms of the vision of the city.

\section{EVALUATION AND CONCLUSION}

Science centers are places where people can come together and explore the very mysteries that make up our world. By encouraging public understanding and engagement with science, they serve as important platforms for the empowerment of people, allowing people to make well-informed decisions. They are also exciting learning places for all ages, essential in enhancing societal capacities to adapt in the face of change. Science centers and museums are considered to have the potential to fulfill a major role in the informal learning of science. Impacts of science centers can be classified as individual, political, social and economic. Also, recent research shows that well established in developed countries, iconic architectural designed science centers have undisputed appeal to a wide range of audiences. The number of iconic science centers continuously increases in the world and with their high number of visitors, they have great impacts on the cities.

With many of its social economic, cultural and infrastructural data, Konya is important city. In this study, the science centers, iconic buildings and their impacts to cities are reviewed by literature study and it is questioned whether Konya Science Center carried image structure mission or not and the structure was analyzed in architectural terms.

It is seen that the aim was constructing an iconic building in the design stage of Konya Science Center, which was built in order to exhibit the new icon of the city, to draw investments and tourists, to make the city a center of culture by being a reference. As a result of analyses, observations and interviews made on the subject, it is determined that Konya Science Center is an icon building for Konya city owing to its different form, material selection, and Leeds certified sustainable building. It is understood that the building is in parallel with developing trends in design and building technology fields. The facility, which has wind energy power plant and solar panels in its building, is an important green building example that is constructed in Turkey. In the light of the data, it is determined that the first Science Center in Turkey that is created with the support of TÜBITTAK is an important attraction point for visitors coming to the city and it provides important contributions in terms of the vision of the city. It is thought that 
Konya Science Center which is the first science center of Turkey that is supported by TÜBITAK will be an example for the iconic science center projects to be designed.

\section{REFERENCES}

Ateşoğlu, İ. (2008). 'Şehir Markası Oluşturmada Sembol Yapıların Etkisi', Yerel Siyaset Dergisi, 17, pp.87-88.

Avcı, Ü. (2015). 'Antalya Kaleiçi'nde Bir Simge Yapı: Yivli Minare', SDÜ Arte-Güzel Sanatlar Fakültesi Sanat Dergisi, 7 (15), pp. 52-78.

Aydın, M. (2010). 'Tübitak Öncülüğünde Türkiye'nin İlk Bilim Merkezi; Konya Bilim Merkezi', Lonca Dergisi, 33, pp. 6-7.

Engez, A. (2007). Küreselleșme Sürecinde Kentlerin İmaj ve Kimlikleri: Karşılaştırılmalı İstanbul Örneği, Marmara Üniversitesi Sosyal Bilimler Enstitüsü, Yüksek Lisans Tezi, İstanbul.

Ekenyazıcı, E. (2005). İkon yapıların turizm eğilimlerine etkileri, YTÜ Fen Bilimleri Enstitüsü, Yüksek Lisans Tezi, İstanbul.

Falk, J. H. and Dierking, L. D. (1992). The museum experience, Washington, D.C.: Whalesback Books.

Gammon, B. (2008). The impact of Science \& Discovery Centres: A review of worldwide studies (E. Kell, Ed.), Retrieved from Association for Science and Discovery Centres: https://www.sciencecentres.org.uk/resources/sciencecentres-worldwide/impact-science-discovery-centresreview-worldwide-studies/.

Hannu, S. (1993). Science Centre Education. Motivation and Learning in Informal Education. Research Report 119, Helsinki University Department of Teacher Education, Doctoral Dissertation, Finland.

Lökçe, S. (2003). İki Şehir İkonu: Sagrada Familia ve Sydney Opera Binası, Gazi Üniv. Müh. Mim. Fak. Dergisi, 18 (1), 89-100, Ankara.

Lucas, A. M. (1983). Scientific literacy and informal learning, Studies in Science Education, 10(1), pp. 1- 36.

Maralcan, M. (2006). Kentler ve ikonları, Tasarım Dergisi, 159, Tasarım Grubu, İstanbul.

Paddison, R. (1993). City marketing, image reconstruction and urban regeneration, Urban Studies, 30(2), pp. 339-350.

Persson, P. E. (2000a). "Community Impact of Science Centers: Is There Any?", Curator: The Museum Journal, 43 (1), pp. 9-17.

Persson, P. E. (2000b). Science centers are thriving and going strong!, Public Understanding of Science, 9(4), pp. 449-460.

Quin, M. (1990). What is hands-on science, and where can I find?, Physics Education, 25 (5), pp. 243-246.

Ramey-Gassert, L. (1996). Same place, different experiences: Exploring the influence of gender students science museum experiences, International Journal of Science Education, 18 (8), pp.903-912.

Ramey-Gassert, L. (1997). Learning science beyond the classroom, The Elementary School Journal, 97(4), pp. 433-450. 
Rennie, L. J. and McClafferty, T. P. (1995). Using visits to Interactive Science and Technology Centres, Museums, Aquaria, and Zoos to promote learning in science, Journal of Science Teacher Education, 6(4), pp.175-185.

Rennie, L. J. and McClafferty, T. P. (1996). Science centres and science learning, Studies in Science Education, 27(1), pp. 5398.

Richards, G. and Wilson J. (2004). The Impact of Cultural Events on City Image: Rotterdam, Cultural Capital of Europe, Urban Studies, 41 (10), pp.1931-1951.

Rix, C. and McSorley, J. (1999). An investigation into the role that school-based interactive science centers may play in the education of primary-aged children, International Journal of Science Education, 21(6), pp. 577-593.

Russell, I. (1990). Visiting a science centre: What's on offer?, Physics Education, 25 (5), pp. 258-262.

URL-1 http://disney.wikia.com/wiki/File:Eiffel_Tower,_Paris.jpg

URL-2 https://www.tourism-of-india.com/taj-mahal-agra.html

URL-3 https://www.everythingaustralia.com/sydney-operahouse-tour-sydney-1099/

URL-4 https://www.guggenheim.org/about-us

URL-5 http://www.yapi.com.tr/haberler/son-10-yilin-engorkemli-10-mimari-yapisi-secildi_74987.html

URL-6 http://www.pinterest.com/pin/407435097519974547/ ?lp=true

URL-7 http://azerbaijan.travel/en/place/185-heydar-aliyevcenter

URL-8 http://time.com/4232532/china-no-more-bizarrearchitecture/

URL-9 https://hu.wikipedia.org/wiki/Turning_Torso\#/media/Fi le:Turningtorso2011.jpg

URL-10 https://www.pinterest.com/pin/144607838005349153

URL-11 https://www.sfgate.com/travel/article/Vivid-Valenciaspans-centuries-with-surprises-2550918.php\#photo2649403

URL-12 https://www.pinterest.com/pin/508977195378575960

URL-13 https://bookbestrate.com/blog/en/93-ramadan-inkuwait-things-to-do

URL-14, https://en.wikipedia.org/wiki/Phaeno_Science_Center

URL-15 https://en.wikipedia.org/wiki/Nagoya_City_Science_Mus eum

URL-16 https://en.wikipedia.org/wiki/Glasgow_Science_Centre

URL-17 https://www.nemosciencemuseum.nl/en/aboutnemo/press/photographs/

URL-18 http://smithgill.com/work/kazakhstan_pavilion_science _museum/

URL-19 https://visuallexicon.wordpress.com/2017/10/13/theartscience-museum-moshe-safdie/

URL-20 http://wowturkey.com/t.php?p=/tr435/konyaturk_7.gif

URL-21 http://www.konya.bel.tr/haberbasin.php?a=bldfoto/14/ bsk/tbt_bm_b_8.jpg\&haberID=4029\&hDurum=FOTO

URL-22 http://www.endeco.com.tr/proje-36-konya-bilimmerkezi.html 
The Importance of Iconic Buildings for City Image: Konya Science Center Example

URL-23 http://www.konyaninsesi.com.tr/ilk-bilim-merkezindeson-asamaya-gelindi-23324h.htm

URL-24 http://www.modulcelik.com.tr/tr/konyapi.aspx

URL-25 http://wowturkey.com/forum/viewtopic.php?t=106061 \& start $=75$

URL-26 http://konhaber.com/haber-konya_bilim_merkezi_turki ye_ye_model_olacak-111676.html

URL-27 http://www.akpartikonya.com/ak-yatirimlar/yatirim /22351_turkiyenin-tubitak-destekli-ilk-bilim-merkezi

URL-28 http://www.konya.bel.tr/haberbasin.php?a=bldfoto/13/ fen/bilim_bs_b_6.jpg\&haberID=3871\&hDurum=FOTO

Weitze, M. D. (2003). "Science Centers: Examples from US and from Germany", From the itinerant lectures of the 18th century to popularizing physics in the 21st centuryexploring the relationship between learning and entertainment, Proceedings of conference held in Pognana sul Lario, Italy.

Wellington, J. (1990). Formal and informal learning in science: The role of interactive science centers, Physics Education, 25 (5), pp. 247-252.

\section{Resume}

She has an undergraduate degree from Selcuk University, Faculty of Engineering and Architecture, Department of Architecture (2008), has masters and Ph.D. degree from Selcuk University, Graduate School of Natural And Applied Sciences (2012-2018). She is working at Konya Technical University, Faculty of Architecture and Design, Department of Architecture since 2008. 